\title{
Bulanık VIKOR Yöntemi ile Özel Huzurevi ve Yaşlı Bakım Merkezlerinde Bakım Elemanı Seçimi ve Değerlendirmesi ${ }^{* \dagger}$ (Araştırma Makalesi)
}

\author{
Care Staff Selection and Evaluation in Private Nursing Houses and Elderly \\ Care Centers with Fuzzy VIKOR Method \\ Doi: 10.29023/alanyaakademik.1007958
}

\author{
Engin KARAKIŞ \\ Dr. Ögrr. Üyesi, Sivas Cumhuriyet Üniversitesi, İktisadi ve İdari Bilimler Fakültesi, \\ Ekonometri Bölümü, \\ ekarakis@cumhuriyet.edu.tr, \\ Orcld No: 0000-0003-1271-1742
}

Bu makaleye atıfta bulunmak için: Karakış, E. (2022). "Bulanık VIKOR Yöntemi ile Özel Huzurevi ve Yaşlı Bakım Merkezlerinde Bakım Elemanı Seçimi ve Değerlendirmesi”, Alanya Akademik Bakış, 6(1), Sayfa No. 1965-1985.

\section{Anahtar kelimeler: \\ Bulanık Çok Kriterli \\ Karar Verme, \\ Bulanik VIKOR, \\ Yaşlı bakım elemanı seçimi,}

Makale Geliş Tarihi: 11.10.2021

Kabul Tarihi:

01.12 .2022

\section{ÖZET}

Özel bakım merkezleri ve huzurevlerinin faaliyetlerini sürdürebilmeleri için nitelikli personel çalıştırmaları çok önemlidir. Bakım merkezleri ve huzurevlerinin eleman alırken ve çalışanlarını değerlendirirken onların mesleki yeterlilikleri yanında kişisel yeterliliklerine de önem verdikleri görülmektedir. Kişisel yeterlilikler gibi nitel ve belirsizlik içeren karar problemlerinin çözümünde bulanık mantık ve bulanık çok kriterli karar verme yöntemlerinden yararlanılmaktadır. Bu çalışmada, bulanık VIKOR yöntemi kullanılarak yaşlı bakım elemanı seçim ve değerlendirmesi için bir karar modeli önerilmiştir. Analizde öncelikle bulanık sayılar kullanılarak eleman seçiminde etkili olan kriterlerin önem ă̆ırlıkları belirlenmiş daha sonra bulanık VIKOR yöntemi ile yaşlı bakım elemanı seçimi yapılmıştır. Eleman seçiminde etkili olan kriterler içinde "Sabırlı ve Strese Dayanıklı Olma", "Empati Yapabilme ve Nazik Olma”, "Fiziksel ve Psikolojik Olarak Dayanıklı Olma” gibi duygusal yeterlilikler önemli bulunmuştur.
Keywords:

Fuzzy Multi Criteria Decision Making, Fuzzy VIKOR, Elderly Care Staff Selection

\begin{abstract}
It is very important for private care centers and nursing homes to employ qualified personnel in order to continue their activities. It is seen that care centers and nursing homes give importance to their personal competencies as well as their professional competencies while hiring and evaluating their employees. Fuzzy logic and fuzzy multi-criteria decision-making methods are used in the solution of qualitative and uncertain decision problems such as personal competencies. In this study, a decision model was proposed for the
\end{abstract}

\footnotetext{
* Bu çalışma 08-10 Eylül 2021 tarihinde Ankara'da gerçekleştirilen 21. Uluslararası Ekonometri Yöneylem Araştırması ve İstatistik Sempozyumunda bildiri olarak sunulmuştur.

$\dagger \mathrm{Bu}$ çalışma için Sivas Cumhuriyet Üniversitesi Bilimsel Araştırma ve Yayın Etiği Sosyal ve Beşeri Bilimler Kurulu'nun 02.09.2021 tarihli ve 10 sayılı kararınca “Etik Kurul Onayı” alınmıştır.
} 
selection and evaluation of an elderly care staff using fuzzy logic and fuzzy VIKOR method. In the analysis, first of all, the importance weights of the criteria that are effective in the selection of staff were determined by using fuzzy numbers, then the elderly care staff was selected with the fuzzy VIKOR method. Emotional competencies such as "being patient and resistant to stress", "being able to empathize and being kind", "being physically and psychologically resilient" were found to be important among the criteria that are effective in the selection of personnel.

\section{GÍRIŞ}

Sanayileşme sürecinde bilim ve teknolojideki gelişmeler insan ömrünün uzamasını sağlamış, bunun sonucunda demografik yapılar değişerek yaşlı nüfus oranı artış göstermiştir. Buna karşın sanayileşme sürecinde doğum oranları azalmıştır. Sanayileşme sürecinde üretim merkezlerinin iş gücü ihtiyacı artmış ve kadınlar çalışma hayatına katılmışlardır. Bu süreçte iş bölümü artarak geleneksel geniş aile yapısı yerini çekirdek aile yapısına bırakmış; eğitim, bakım gibi temel ihtiyaçlar aile dışındaki kurumlar tarafından karşılanmaya başlanmıştır. Bu yapıda toplumun yaşlı bireyleri yalnız kalmış; fiziksel, psikolojik ve sosyal engeller nedeniyle günlük yaşam faaliyetlerini sürdürmek için yardıma ve bakıma ihtiyaç duyar olmuştur.

Sanayileşme sürecinde kadınların ve tüm aile bireylerinin evin dışında çalışma hayatına girmesi ile ailelerin yardıma ve bakıma ihtiyaç duyan yaşlı bireyleri yalnız kalmıştır. Yaşlı bireylerin daha önceleri aile içinde karşılanan bakım hizmetleri, kamu kurum ve kuruluşları tarafından karşılanmaya ya da bu alanda faaliyet gösteren özel girişimler tarafından karşılanmaya başlanmıştır. Günümüzde hem kamu kuruluşları hem de özel girişimler yaşlı bireylere bakım hizmeti sunmaktadır. Bu kuruluşların sayısı yaşlı nüfusun artmasına bağlı olarak artmaktadır. Türkiye'de 65 yaş üstündeki yaşlı nüfus 2019 yılı verilerine göre 7.550 .727 olup bu toplam nüfusun \%9.1'ini oluşturmaktadır (TÜİK, 2021). Ülkemizde 2021 y1lı verilerine göre 163 'ü ilgili bakanlığa, 21'i diğer kamu kurumlarına, 266'sı özel girişimlere ait toplam 450 adet huzurevi ve bakım merkezinde toplamda 27.113 yaşlıya bakım hizmeti sunulmaktadır (Aile ve Sosyal Hizmetler Bakanlığı, 2021). Yaşlı nüfusun artmaya başlaması ile bu alanda uzman ve tecrübeli elemana duyulan ihtiyacın arttığı görülmektedir. Yaşlı bakımı hizmeti Türkiye'de ilk defa 1963 yılında Sağlık Sosyal Yardım Bakanlığına bağlı Sosyal Hizmetler Genel Müdürlüğünün kurulması ile başlamıştır. Daha sonra 1982 Anayasası'nda yaşlıların korunması yer almıştır. Başlangıçta kamu sektöründe başlayan bakım hizmetleri daha sonra özel huzurevleri ve yaşlı bakım merkezleri tarafından da verilmeye başlanmıştır (Yalılı vd. 2016: $33)$.

Dünyada artan yaşlı nüfus, yaşlı bakım merkezlerine olan talebi ve duygusal emek olarak da nitelenen yaşlı bakım elemanlarına olan talebi artırmaktadır (Erebak ve Tarhan, 2018: 115). Çok hassas ve özel bir çalışma alanı olan yaşlı bakımının özel yetenek ve becerilere sahip kişilerce yürütülen, zor bir hizmet alanı olduğu görülmektedir. Bu bağlamda bakım elemanlarının, mesleki bilgi ve tecrübeleri yanında onların mesleki etik değerler, sabır, sevgi, şefkat, mahrumiyete ve gizliliğe saygı gibi temel iletişim becerileri ve duygusal yeterliliklerinin önemli olduğu görülmektedir. Yaşlı bakımı gibi hizmet sektöründe faaliyet gösteren kuruluşların en önemli kaynağı nitelikli çalışanlarıdır. Özel bakım merkezleri ve huzurevlerinde doğru kişilerin istihdam edilmesi ve performanslarının doğru değerlendirilmesi bu kuruluşların kaliteli hizmet sunması, kârlı ve sürekli olmasını sağlamaktadır. Bu nedenle 
yaşı bakımı konusunda çalışacak olan adayların seçimi ve performans değerlendirmesinde karar vericilerin bilimsel yöntemler kullanması çok önemlidir.

Bu çalışmada özel yaşlı bakım merkezi ve huzurevlerinde çalışmak üzere bakım elemanı seçimi ve değerlendirmesi problemi ele alınmıştır. Yaşlı bakım elemanı seçimi ve değerlendirmesi çok sayıda kriterin dikkate alınmasını gerektiren bir Çok Kriterli Karar Verme (ÇKKV) problemidir. Yaşlı bakım elemanı seçiminde etkili olan kriterler arasında nitel kriterler bulunması nedeniyle problem belirsizlik ve bulanıklık içermektedir. Bu nedenle bakım elemanı seçimi ve değerlendirmesinde bulanık ÇKKV yöntemi önerilmiştir. Çalışmada yaşlı bakım elemanı seçiminde etkili olan kriterlerin önem ağırlıkları bulanık mantıkla belirlenmiş ve yaşlı bakım elamanı seçiminde bulanık VIKOR (VIseKriterijumska Optimizacija I Kompromisno Resenje) yöntemi kullanılmıştır. Bulanık VIKOR yönteminde üçgen bulanık sayılar kullanılmıştır. Bu çalışma, yaşıı bakım elemanı seçimi için uzman görüşmeleri ve literatür taraması ile belirlenen kriterler ve bu yeni kriterleri içeren seçim probleminin çözümünde bulanık yöntem önerisi ile literatüre katkı sağlayacaktır.

Çalışmada bulanık VIKOR yöntemi uzlaşık bir çözüm önermesi nedeniyle tercih edilmiştir. VIKOR yöntemi maksimum grup faydası ve minimum pişmanlığı sağlamaktadır. Çalışmada kullanılan VIKOR yöntemi TOPSIS yöntemine göre daha yeni bir yöntemdir. VIKOR yöntemi TOPSIS yöntemi ile benzer yaklaşımları kullanarak ideal çözüme uzaklıklarına göre alternatifleri sıralamaktadır. Ancak VIKOR yöntemi ideal çözüme en yakın ve negatif çözüme en uzak alternatifi oran olarak hesaplayarak avantajlı çözümü belirler. (Amiri vd. 2011: 68; Ertuğrul ve Özçil, 2014: 270). VIKOR yöntemi uzlaşık çözüme dayalı olduğu için karar verici uzlaşma ile belirlenecek olan çözümü benimsemeye hazır olmalıdır. Bu özellik bir karar vericinin eksik ve yanlış değerlendirme yapması halinde bu eksikliğin etkilerinin grup kararı ile belirlenen uzlaşık çözümün kabul edilmesi ile giderilebileceğini gösterir.

Çalışmanın birinci bölümünde karar problemi tanımlanarak ikinci bölümünde literatür taraması yapılmıştır. Üçüncü bölümde bulanık mantık, bulanık küme teorisi ve bulanık VIKOR yöntemleri açıklanmıştır. Çalışmanın dördüncü bölümünde bulanık VIKOR yöntemi ile yaşıı bakım elemanı seçimi yapılmıştır. Çalışmanın son bölümünde sonuç ve değerlendirmelere yer verilmiştir.

\section{LITERATÜR TARAMASI}

Bulanık mantık ve bulanık sayılar belirsizlikler içeren karar problemlerinin çözümünde sıklıkla kullanılmaktadır. Bulanık mantık ve bulanık VIKOR yönteminin başta işletme problemleri olmak üzere sağlık, mühendislik gibi pek çok alanda kullanıldığı görülmektedir. Personel seçimi konusunda literatürde ÇKKV yöntemlerinin kullanıldığ 1 çok sayıda araştırma yapıldığı görülmektedir. Bu kısımda öncelikle oldukça zengin bir literatür içinden bulanık VIKOR yöntemi ile personel seçimi ve değerlendirilmesi yapılan çalışmalara daha sonra konu bazlı olarak farklı yöntemlerle çeşitli sektörler için personel seçimi yapılan araştırmalara yer verilmiştir.

Öztürk ve Kaya (2020) bulanık mantık, bulanık VIKOR yöntemiyle otomotiv yan sanayisinde personel seçimi yapmışlardır. Alguliyev vd. (2015) önerdikleri bulanık VIKOR yöntemi ile belirledikleri beş kritere göre beş doktora öğrencisini değerlendirmişlerdir. Yıldız ve Deveci (2013) Bulanık VIKOR yöntemi ile bir teknoloji firması için personel seçimi yapmışlardır. Çalışmalarında üçgen bulanık sayıları kullanmışlardır. Salehi (2016) bulanık AHP ve bulanık VIKOR bütünleşik karar modeli ile yedi kritere göre, üçgen bulanık sayılar kullanarak personel 
seçimi yapmıştır. Krishankumar vd. (2020), önerdikleri bulanık VIKOR yöntemiyle personel seçimi ve değerlendirmesi yapmışlardır. Nalbant ve Özdemir (2018) yamuk bulanık sayılarla bulanık VIKOR yöntemini kullanarak personel seçimi yapmışlardır. Yavuz ve Deveci (2014) bulanık TOPSIS ve bulanık VIKOR yöntemleri ile alışveriş merkezi için kuruluş yeri seçimi yapmışlardır. Korkusuz ve Kara (2021), bulanık DEMATEL ve bulanık VIKOR yöntemleri ile bir imalat işletmesi için insan kaynakları yöneticisi seçmişlerdir. Bali (2013) bulanık boyut analizi ve bulanık VIKOR yöntemiyle personel seçimi yapmıştır. Ersoy (2017) bulanık VIKOR yöntemi ile bir lojistik firması için personel seçimi yapmıştır. Akyüz (2012) bulanık VIKOR yöntemiyle tedarikçi seçimi yapmıştır. Hamurcu ve Tamer (2018) kent içi ulaşım için proje seçimini bulanık AHP tabanlı bulanık VIKOR yöntemi ile yapmışlardır. Liang vd. (2019) bulanık VIKOR ile bankaların internet sitesi kalitelerini değerlendirmişlerdir. Suh vd. (2019) bulanık VIKOR yöntemi ile mobil hizmetleri kalitesini değerlendirmişlerdir.

Türeli ve Davraz (2016) araştırmalarında hastanelerde hizmet kalitesinin temel belirleyicisinin personel olduğunu belirtmişlerdir. Özel hastaneler için AHP ve VIKOR yöntemi ile personel seçimi gerçekleştirdikleri çalışmada cinsiyet, tecrübe, eğitim düzeyi, iletişim becerisi, fiziksel özellikleri, kişilik özellikleri ve devamlılık kriterlerini kullanmışlardır. Kriterlerin önem ağırlıklarını AHP yöntemiyle belirledikleri çalışmada alternatiflerin değerlendirmesini VIKOR yöntemi ile yapmışlardır.

Pelit ve Ak (2018) turizm sektörü özelinde personel seçimini geniş bir perspektifle inceledikleri çalışmalarında insan kaynakları yönetiminin en temel ve en önemli işinin personel seçimi olduğunu ifade etmişlerdir. Çalışmada, işletme başarısının en önemli bileşeninin insan kaynağı olduğu vurgulanarak bu amaçla işletmelerde stratejik insan kaynakları biriminin önemine değinilmiş, personel seçme sürecinin geleneksel yöntemler dışında eğitimli ve uzman kadrolar tarafından yapılmasının önemi vurgulanmıştır. İnsan kaynakları birimi içinde özel bir ayrı birim ile işe alım sürecinin daha titiz ve doğru yürütülmesini önermişlerdir.

Kuşakcı vd. (2019) yaptıkları çalışmada bir hava yolu şirketi için uzman seçimi problemini bulanık MULTIMMOORA yöntemiyle incelemişlerdir. Araştırmada üç adayı, üç üst düzey yönetici kurumsal kültür, mesleki yeterlilikler ve kurumsal yeterlilikler ana kriterleri altında yer alan sekiz kritere göre değerlendirmiştir. Bulunan sonuçlar AHP-TOPSIS yöntemi sonuçları ile karşılaştırılarak yöntemin geçerliliği kontrol edilmiştir. MULTIMOORA ve AHPTOPSIS yöntemlerinin aynı sonuçları verdiği ifade edilmiştir.

Adalı (2016) bir hastane için hemşire seçimi problemini EVAMIX ve TODIM yöntemleriyle incelemiştir. Araştırmada sözlü iletişim yeteneği, ekip çalışmasına yatkınlık, yönetim ve organizasyon yeteneği, deneyim, maliyet kriterlerine göre beş aday değerlendirilmiştir.

Esen vd. (2019) yaptıkları araştırmada bir araştırma hastanesine başvuran sertifikalı acil bakım hemşiresi programına başvuran adaylar arasında seçim gerçekleştirmişlerdir. Çalışmalarında; başvuru yapılan il, ilgili alanda çalışma durumu, başvurunun yapıldığ 1 hastanede sertifikalı oranı, birimde çalışma süresi, eğitim durumu ve yaş kriterlerine göre AHP ve TOPSIS yöntemini kullanarak yirmi yedi aday değerlendirilmiştir.

Çelikbilek (2018) sağlık sektöründe yönetici seçimi gerçekleştirmiştir. Çalışmada genel kriterler, karakter kriterleri, sektörel kriterler ve acil durum kriterleri olmak üzere dört ana kriter altında yer alan yirmi kritere göre beş aday gri AHP-MOORA yöntemi kullanılarak değerlendirilmiştir. 
Literatürde sağlık personeli seçimi dişında personel seçiminin çeşitli yöntemlerle incelendiği görülmektedir. Bu çalışmalardan bazıları, Ünal (2011) AHP ile mühendislik bölümü yönetici adayı seçimi; Aksakal ve Dağdeviren (2010) bir firma için DEMATEL ve ANP yöntemi ile mühendis seçimi; Ayçin (2020) bir firmanın bilgi sistemleri bölümü için CRITIC ve MAIRCA yöntemleriyle eleman seçimi; Koyuncu ve Özcan (2014) otomotiv sektöründe bir firma için AHP ve TOPSIS ile personel seçimi; Yıldırım vd. (2019) hava yolu sektöründe ARAS yöntemi ile destek personeli seçimi; Organ ve Kenger (2018) Bulanık AHP ve Bulanık MOORA yöntemleriyle bir zincir market için personel seçimi; Vargün vd. (2020) Entropi temelli MAUT yöntemiyle muhasebe elemanı seçimidir.

\section{BULANIK ÇOK KRITTERLİ KARAR VERME}

Bu çalışmada özel bakım merkezleri ve huzurevlerinde çalıştırmak üzere bakım elemanı seçimi ile ilgili olarak bulanık çok kriterli karar modeli önerilmektedir. Eleman seçimi gibi bulanıklık içeren karar problemlerinde bulanık mantık çok kriterli karar verme yöntemleri ile daha gerçekçi çözümler sunmaktadır. Mesleki yeterliliklerin ve kişisel yeteneklerin değerlendirilmesindeki belirsizliğin modele katılarak dikkate alınması bulanık mantık ile sağlanmaktadır. Bu çalışmada önerilen model Şekil 1'de gösterilmiştir.

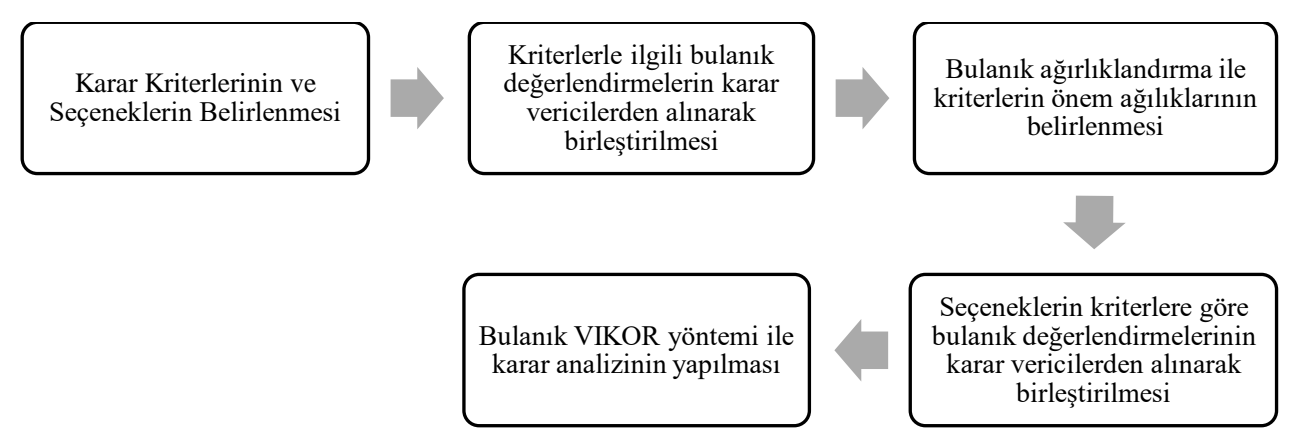

Şekil 1. Önerilen Bulanık Çok Kriterli Karar Verme Yönteminin Adımları

\subsection{Bulanık Kümeler ve Bulanık Sayılar}

Klasik mantık bir nesnenin bir kümeye üyeliğini doğru ve yanlış olmak üzere iki değerli olarak ifade eder. Aristo tarafından ileri sürülen klasik mantık olayların idealize edilmesi düşüncesine dayanmaktadır. Ancak olayları iki değere indirgeyen klasik mantık idealize edilemeyen olay ve olgularda geçerliliğini yitirmiş, bunun yerine insanın düşünme biçimini daha iyi ifade eden bulanık mantık ve bulanık kümeler kullanılmaya başlanmıştır (Zadeh, 1965). Günümüzde incelenen sorunların pek çoğunda özellikle dilsel ifadelerin bulunduğu durumlarda bulanıklığın olduğu görülmektedir. Bulanıklık matematiksel modellerde bulanık mantık ve bulanık kümeler yoluyla modellenmektedir. Bulanık durumların dilsel olarak ifade edilmesinde ve değerlendirilmesinde keskin ayrımlar yerine süreklilik ve çok değerlilik söz konusudur. Örneğin tecrübe değişkeni bulanık mantık diğer bir ifade ile çok değerli mantık çerçevesinde değerlendirildiğinde, bir çalışanın tecrübe durumunun, 0 ya da 1 olmak üzere iki değerli olarak ifade edilmesi gerçekçi değildir. Buna karşın tecrübe değişkenini bulanık kümeler teorisine göre 0 ile 1 arasında farklı üyelik dereceleri ile farklı tecrübe kümelerinde incelenmesi daha gerçekçi bir yaklaşımdır. Şekil 2'de görüldüğ̈̈ gibi dört yıl iş tecrübesi olan bir çalışan, 
“tecrübesiz” kümesinin elemanı değilken “az tecrübeli” kümesinin düşük dereceli bir elemanı, "biraz tecrübeli" kümesinin yüksek dereceli bir elemanıdır. Dört yıl tecrübeli çalışan "tecrübeli" kümesinin düşük dereceli bir elemanı, "çok tecrübeli” kümesinin ise elemanı değildir. Şekil 2'de tecrübe değişkenine üçgen bulanık sayılar kullanılarak üyelik derecesi ataması yapılmıştır. Bulanık kümelerde bir değişkenin bir durumdan diğerine geçişinin yumuşak ve sürekli olduğu görülür (Şen, 2009: 73).

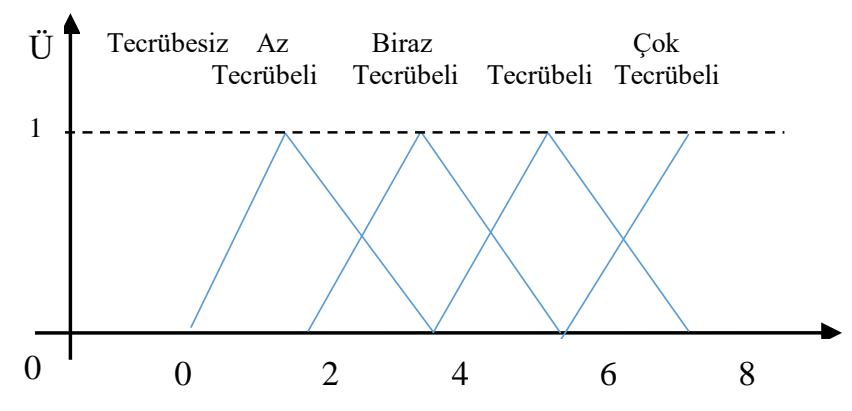

Şekil 2. Tecrübe Değişkeninin Bulanık Alt Kümeleri

Klasik kümelerde bir elemanın küme üyeliliği 1 ve üye olmayışı 0 ile gösterilirse bulanık küme elemanı 0 ile 1 değeri arasında bir derece ile aynı zamanda farklı kümelerin de üyesi olabilmektedir.

\subsection{Bulanık Sayılar}

Bulanık kümelerde işlemler bulanık sayılar ile yapılır. Bulanık sayılar reel sayılardan farklı olarak aralık değerler içeren sayılardır. Bulanık sayılar insan düşünüşünü yansıtacak şekilde yaklaşık değerler ifade etmektedir. Uygulamada en çok kullanılan bulanık sayılar üçgen ve yamuk bulanık sayılardır. Şekil 3’te üçgen bulanık sayı gösterilmiştir.

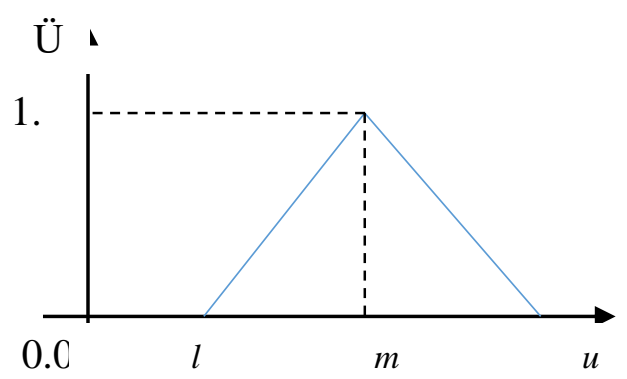

Şekil 3. Üçgen Bulanık Sayı

Üçgen bir bulanık sayısı $\tilde{A}=(1, \mathrm{~m}, \mathrm{u})$ biçiminde gösterilir. Üçgen bulanık sayıda $l$, en küçük değeri $m$, olası değeri ve $u$, ise bulanık sayının en büyük değerini ifade eder.

Bulanık küme, sürekli üyelik dereceleri olan bir nesne sınıfıdır. Üyelik fonksiyonları bulanık küme içindeki her nesneye sıfır ile bir arasında değişen bir üyelik derecesi atar (Kahraman vd. 2004: 174). Üyelik fonksiyonları bulanık bir küme içindeki noktaların farklı üyelik derecelerini gösterir. Üyelik fonksiyonu bir ögenin bulanık kümeye ait olma derecesini veren bir 1970 
fonksiyondur (Paksoy vd. 2013: 33). $\tilde{\mu}(X)$ bir bulanık sayıyı ifade etmek üzere üçgen bulanık sayının üyelik fonksiyonu aşağıda formül (1) ile gösterilebilir;

$$
\widetilde{\mu}(x)=\left\{\begin{array}{cl}
0, & x \leq l \\
\frac{x-l}{m-l}, & l \leq x \leq m \\
\frac{u-x}{u-m}, & m \leq x \leq u \\
O, & u \leq x
\end{array}\right.
$$

Bulanık karar modellerinde bulanık sayılarla matematiksel işlemler yapılarak yine bulanık sayılarla ifade edilen çıktılara ulaşılır. Ulaşılan bu bulanık küme çıktılarının kesin sayılara dönüştürülmesi için bulanık sayılar durulaştırılarak çıkarım yapılır. Durulaştırma bulanıklaştırma işleminin bir anlamda tersidir. Durulaştırma işlemleri de üyelik fonksiyonu aracılığ 1 ile yapılır.

\subsection{Bulanık VIKOR}

VIKOR (VIseKriterijumska Optimizacija I Kompromisno Resenje) yöntemi Opricovic ve Tzeng tarafından 2004 yılında geliştirilen bir ÇKKV yöntemidir. Bulanık VIKOR yöntemi bulanık ve birbiriyle çelişen çok sayıda karar kriterinin bulunduğu karar problemlerinin çözümünde kullanılan bir yöntemdir. Bulanık VIKOR yöntemi uzlaşık çözüme dayalı bir yöntemdir. Uzlaşık çözüm ideal çözüme en yakın uygun çözümdür. Yöntem, grup faydasını maksimum ve bireysel pişmanlığı minimum yapacak uzlaşık çözümü bulmayı sağlar. Alternatifler ideal çözüme yakınlığa göre sıralanır. VIKOR yöntemi, yakınlık ölçüsüne dayalı bir sıralama endeksi ortaya koyar (Opricovic ve Tzeng, 2004: 454). Bulanık ÇKKV yöntemlerinden Bulanık VIKOR yönteminin işlem adımları aşağıdaki gibidir (Opricovıc 2011, Y1ldız ve Deveci 2013):

Adım 1. Bulanık VIKOR yönteminde öncelikle karar verici kişi ya da grup, alternatifler ve alternatiflerin değerlendirildiği karar kriterleri belirlenir. Bu ilk aşama karar probleminin açık ve anlaşılır bir tanımlamasını ifade eder.

Adım 2. Daha sonra n sayıda karar vericinin, m sayıda alternatifi, k sayıda kritere göre bulanık sayılarla değerlendirebilmeleri için değişkenler ve bulanık sayı değerleri belirlenir. Tablo 1'de karar vericilerin kriterlerin önem ağırlığını belirlemek ve alternatifleri değerlendirmek için kullandıkları dilsel değişkenler ile bu değişkenlerin bulanık sayı değerleri verilmiştir.

Tablo 1. Kriterlerin önem ağırıklarını ve alternatifleri değerlendirmek için dilsel değişkenler ve bulanık sayı değerleri.

\begin{tabular}{llll}
\hline \multicolumn{2}{l}{ Kriter ağırıkları için dilsel değerlendirme } & \multicolumn{2}{l}{ Alternatiflerin dilsel değerlendirmesi } \\
\hline Dilsel Değişken & Üçgen bulanık sayı & Dilsel değişkenler & Üçgen bulanık sayı \\
\hline Çok Yüksek (ÇY) & $(0,911)$ & Çok İyi (Çİ) & $(91010)$ \\
\hline Yüksek (Y) & $(0,70,91)$ & İyi (İ) & $(7910)$ \\
\hline Biraz Yüksek (BY) & $(0,50,70,9)$ & Biraz İyi (Bİ) & $(579)$ \\
\hline Orta (O) & $(0,30,50,7)$ & Orta (O) & $(357)$ \\
\hline Biraz Düşük (BD) & $(0,10,30,5)$ & Biraz Kötü (BK) & $(135)$ \\
\hline
\end{tabular}


KARAKIŞ

\begin{tabular}{|c|c|c|c|}
\hline Düşük (D) & $\left(\begin{array}{lll}0 & 0,1 & 0,3\end{array}\right)$ & Kötü (K) & $\left(\begin{array}{lll}0 & 1 & 3\end{array}\right)$ \\
\hline Çok Düşük (ÇD) & $\left(\begin{array}{lll}0 & 0 & 0,1\end{array}\right)$ & Çok Kötü (ÇK) & $\left(\begin{array}{lll}0 & 0 & 1\end{array}\right)$ \\
\hline
\end{tabular}

Adım 3. Bu adımda n sayıdaki karar verici kriterlerin önem ağırlıklarını bulanık sayılarla değerlendirirler. Bu adımda karar vericilerin bu değerlendirmeleri birleştirilerek her bir kriterin bulanık önem ağırlıkları elde edilir. $\tilde{w}_{j}$, j. kriterin önem ağırlığını göstermek üzere kriterlerin birleştirilmiş bulanık önem ağırlıkları aşağıdaki formül ile hesaplanır. $\widetilde{w}_{j}=\frac{1}{n}\left[\widetilde{w}_{j}^{1}+\widetilde{w}_{j}^{2}+\widetilde{w}_{j}^{3}+\ldots . .+\widetilde{w}_{j}^{k}\right], \quad j=1,2,3, \ldots . . k$

Kriterlerin bulanık önem ağırlıklarının bulunmasından sonra n sayıda karar verici alternatifleri Tablo 1'de yer alan dilsel değişkenler ile değerlendirir. Bu değerlendirmeler birleştirilerek alternatiflerin kriterlere göre değerlendirmeleri hesaplanır. $\tilde{x}_{i j}$ i alternatifin j. kritere göre aldığı bulanık sayı değerlerinin birleştirilmesi sonucunda aldığı değeri gösterir.

$$
\tilde{x}_{i j}=\frac{1}{n}\left[\tilde{x}_{i j}^{1}+\tilde{x}_{i j}^{2}+\tilde{x}_{i j}^{3}+\ldots . .+\tilde{x}_{i j}^{k}\right], \quad i=1,2,3, \ldots . . m
$$

Adım 4. Kriterlerin ve alternatiflerin değerlendirilmesinden sonra bulanık karar matrisi ve bulanık önem ağırlıkları vektörü elde edilir.

$$
\begin{aligned}
& \tilde{M}=\left[\begin{array}{cccc}
\tilde{x}_{11} & \tilde{x}_{12} & \ldots & \tilde{x}_{1 j} \\
\tilde{x}_{21} & \tilde{x}_{22} & \ldots & \tilde{x}_{2 j} \\
\vdots & \vdots & \ddots & \ldots \\
\tilde{x}_{i 1} & \tilde{x}_{i 2} & \ldots & \tilde{x}_{i j}
\end{array}\right] \quad i=1,2,3, \ldots \ldots m \quad j=1,2,3, \ldots \ldots \ldots k \\
& \tilde{w}_{j}=\left[\tilde{w}_{j}+\tilde{w}_{j}+\tilde{w}_{j}+\ldots \ldots . \tilde{w}_{j}\right] \quad j=1,2,3, \ldots \ldots \ldots . . k
\end{aligned}
$$

$\tilde{x}_{i j}$ i. alternatifin j. kritere göre aldığı bulanık sayı değerini ifade ederken, $\tilde{w}_{j} \mathrm{j}$. kriterin önem ağırlığını gösterir.

Adım 5. Her bir kriter için bulanık en iyi ve bulanık en kötü değer belirlenir. Bulanık en iyi değer $\tilde{f}_{j}^{*}$ ve bulanık en kötü değer $\tilde{f}_{j}^{-}$ile gösterilir. En iyi ve en kötü değerler kriterlerin fayda ya da maliyet nitelikli oluşuna göre formül (6) ve formül (7) kullanılarak belirlenir.

$$
\begin{aligned}
& \tilde{f}_{j}^{*}=\max _{j} x_{i j} \\
& \tilde{f}_{j}^{-}=\min _{j} x_{i j}
\end{aligned}
$$

Eğer kriter maliyet nitelikli ise $\tilde{f}_{j}^{*}$ ve $\tilde{f}_{j}^{-}$değerleri; 


$$
\begin{aligned}
& \widetilde{f}_{j}^{*}=\min _{j} \tilde{x}_{i j} \\
& \widetilde{f}_{j}^{-}=\max _{j} \widetilde{x}_{i j}
\end{aligned}
$$

Adım 6. $\tilde{S}_{j}$ ve $\tilde{R}_{j}$ ve değerlerinin hesaplanması ; $\tilde{S}_{j}$ alternatiflerin en iyi değere uzaklıkları toplamı, $\tilde{R}_{j}$ değeri j. kritere göre i. alternatifin bulanık en kötü değerlere maksimum uzaklığıdır. $\tilde{S}_{j}$ ve $\tilde{R}_{j}$ ve değerleri $\mathrm{j}=1,2,3, \ldots \ldots$. n çin formül (8) ve (9) kullanılarak hesaplanır.

$$
\begin{aligned}
& \widetilde{S}_{j}=\sum_{j=1}^{n}\left[w_{i}\left(\tilde{f}_{i}^{*}-x_{i j}\right) /\left(f_{i}^{*}-f_{i}^{-}\right)\right] \\
& \widetilde{R}_{j}=\max \left[w_{i}\left(\widetilde{f}_{i}^{*}-x_{i j}\right) /\left(\widetilde{f}_{i}^{*}-\widetilde{f}_{i}^{-}\right)\right]
\end{aligned}
$$

Adım 7. $\tilde{S}_{j}$ ve $\tilde{R}_{j}$ ve değerlerinin hesaplanmasından sonra maksimum grup faydası değerleri hesaplanır.

$$
\begin{aligned}
\widetilde{S}^{*}=\min _{i} \tilde{S}_{i}, & \tilde{S}^{-}=\max _{i} \widetilde{S}_{i} \\
\widetilde{R}^{*}=\min _{\hat{\imath}} \widetilde{R}_{i}, & \widetilde{R}^{-}=\max _{i} \widetilde{R}_{i}
\end{aligned}
$$

$\tilde{S}^{*}$ maksimum grup faydasını ifade ederken $\tilde{R}^{*}$, karşı görüştekilerin minimum pişmanlığını ifade eder. Bu değerler ile maksimum grup faydasının ağırlık değeri, 'v' ve bireysel pişmanlık ağırlığını ifade eden, (1-v) değeri kullanılarak $\tilde{Q}_{i}$ indeks değeri hesaplanır.

$$
\tilde{Q}_{i}=\frac{v\left(\tilde{S}_{i}-\tilde{S}^{*}\right)}{\left(\tilde{S}^{-}-\tilde{S}^{*}\right)}+\frac{(1-v)\left(\tilde{R}_{i}-\tilde{R}^{*}\right)}{\left(\tilde{R}^{-}-\tilde{R}^{*}\right)}
$$

Uzlaşma, çoğunluk ile $\mathrm{v}>0,5$, konsensüs $\mathrm{v}=0,5$ ve veto durumunda $\mathrm{v}<0,5$ ile sağlanabilir (Opricovic ve Tzeng, 2007: 516). $\tilde{Q}_{i}$ bulanık indeks değeri belirlenen durulaştırma yöntemi ile durulaştırılarak $Q_{i}$ indeksi elde edilir.

Adım 8. Bu aşamada $S_{i}, R_{i}$ ve $Q_{i}$ indeks değerleri elde edildikten sonra alternatifler sıralanır. İndeks değerinin en küçük olduğu alternatif en iyi alternatif olarak belirlenir. Bu çalışmada Hsieh vd. (2004) tarafindan önerilen (Best Nonfuzzy Performance Value) formülü (13) ile durulaştırma yapılmıştır.

$$
B N P \dot{I}=\frac{\left(u_{i}-l_{i}\right)+\left(m_{i}-l_{i}\right)}{3}+l_{i}
$$

Adım 9. Elde edilen çözümün uzlaşık çözüm olup olmadığını belirlemek için aşağıdaki koşulların sağlanması gereklidir: 
Koşul 1. Kabul edilebilir avantaj koşulu: Bu koşul en iyi alternatif ile bu alternatife en yakın çözüm arasında bir fark olduğunu gösterir. Formül (14)'te $a_{1}$ birinci sıradaki alternatifi ve $a_{2}$ ikinci sırada olan, birinciye en yakın alternatifi ifade etmektedir.

$Q\left(a_{2}\right)-Q\left(a_{1}\right) \geq D Q$

$D Q=\frac{1}{m-1}, \mathrm{~m}$ alternatif sayısını ifade etmek üzere $\mathrm{m} \leq 4$ ise $\mathrm{DQ}=0,25$

Koşul 2. Karar vermede kabul edilebilir istikrar koşulu: Bu koşul elde edilen çözümün istikrarlı olmasını içerir. $Q_{i}$ indeks değerleri küçüktün büyüğe sıralandığında ilk sıradaki alternatif $S_{i}$ ve $R_{i}$ değerlerinin sıralanmasında da ilk sırada en küçük değer olmalıdır.

Kabul edilebilir avantaj ve kabul edilebilir istikrar koşulların birinin sağlanması gereklidir. Aksi halde birden fazla uzlaşık çözüm olduğu kabul edilir. Bu durumda aşağıdaki uzlaşık çözümler önerilir:

a. Eğer birinci koşul sağlanmaz ise ve alternatiflerin tamamı uzlaşı çözüm olarak kabul edilir. Bu durumda uzlaşık çözüm üst sınır L'ye göre belirlenir.

$Q\left(a_{L}\right)-Q\left(a_{1}\right) \leq D Q$

$L, Q_{i}$ sıralamasında en yüksek alternatif değerini gösterir. $Q_{i}$ sıralamasında eşitsizlik (16)'y1 sağlayan son alternatifin değeri $L$ ile gösterilir. Uzlaşı çözüm kümesindeki alternatifler $Q_{i}$ değerlerine göre sıralanarak en küçük $Q_{i}$ değerine sahip alternatif en iyi alternatif olarak belirlenir.

b. Eğer ikinci koşul sağlanmıyorsa $a_{1} v e a_{2}$ alternatiflerinin her ikisi de uzlaşık çözüm kabul edilir.

\section{BULANIK VIKOR YÖNTEMIYYLE YAŞLI BAKIM ELEMANI SEÇIMI}

Yaşlı bakım elemanı seçiminde etkili olan kriterler, literatür taraması ve özel yaşlı bakım merkezi ve huzurevi yöneticisi olan uzman bir grup ile yapılan görüşmeler sonucunda belirlenmiştir. Görüşmeler, özel yaşlı bakım merkezi ve huzurevi yöneticisi dört uzman ve ayrıca bu merkezlerde danışman ve sosyal hizmet uzmanı olarak çalışan beş uzman olmak üzere toplam dokuz kişi ile yapılmıştır. Yönetici olan dört uzmandan ikisi kamu kurumu niteliğindeki yaşlı bakım merkezinde yönetici olup eğitim fakültesi Türk Dili ve Edebiyatı Bölümü ve Sosyal Hizmetler Bölümü mezunudur. Diğer iki yönetici özel kurumlarda çalışmakta ve Sosyal Hizmetler Bölümü mezunudur. Görüşülen diğer beş uzman özel bakım merkezi ve huzurevlerinde çalışmakta olup bu uzmanlardan biri Sosyoloji Bölümü mezunu, biri Sağlık Bilimleri Fakültesi Hemşirelik Bölümü mezunu ve diğer üç uzman ise Sosyal Hizmetler Bölümü mezunudur. Yaşları 35-55 olan erkek yöneticiler evli olduklarını belirtmişlerdir. Sosyoloji mezunu dışındaki diğer uzmanlar da evli olduklarını belirtmişlerdir. Sosyoloji mezunu olan uzman 26, hemşire 27 yaşındadır; Sosyal Hizmetler Bölümü mezunu olan diğer üç uzman 28-45 yaşları arasındadır. Uzmanlar, üniversite eğitimi sırasında stajlarını bu kurumlarda yaptıklarını ve üniversite eğitimlerinden sonra bu alanda çalışmaya devam 
ettiklerini belirtmişlerdir. Yaşlı bakım elemanı seçim ve değerlendirmesinde etkili olan yedi kriter belirlenmiştir. Belirlenen karar kriterleri Tablo 2'de verilmiştir.

Tablo 2. Seçim ve Değerlendirme Kriterleri

\begin{tabular}{ll}
\hline Kodu & Değerlendirme Kriterleri \\
\hline$C_{1}$ & Mesleki bilgi \\
\hline$C_{2}$ & Tecrübe \\
\hline$C_{3}$ & Sabırlı Olma ve Strese dayanıklı olma \\
\hline$C_{4}$ & Empati Yapabilme ve Nazik Olma \\
\hline$C_{5}$ & Mahremiyete ve Özel hayatın Gizliliğine Saygılı olma \\
\hline$C_{6}$ & Fiziksel Olarak Dayanıklı Olmak \\
\hline$C_{7}$ & Her türlü İstismara Kapalı olmak \\
\hline
\end{tabular}

Yaşlı bakım elemanı seçiminde etkili olan kriterlerin belirlenmesinde yararlanılan bazı araştırmalar ve kullandıkları değerlendirme kriterleri Tablo 3.'te verilmiştir. Değerlendirme kriterlerinin belirlenmesinde uzmanlarla yapılan görüşmeler ile bakım personelinin sorunlarına ilişkin yapılan araştırma bulgularının örtüştüğü görülmüştür. Bakım elemanlarının yaptıkları işin zorlukları nedeniyle tükenmişlik, duyarsızlaşma, yabancılaşma, fiziksel yorgunluk gibi problemlerle karşı karşıya kaldıkları ve iş doyumlarının azaldığı yapılan çalışmalarda vurgulanmıştır.

Tablo 3. Personel seçimi ve değerlendirilmesinde kullanılan kriterler

\begin{tabular}{llll} 
Araştırmacı & Araştırma alanı & Araştırmada Kullanılan kriterler \\
\hline $\begin{array}{l}\text { Türeli ve Davraz } \\
(2016)\end{array}$ & $\begin{array}{l}\text { Özel bir hastane } \\
\text { personel seçimi }\end{array}$ & için & $\begin{array}{l}\text { Cinsiyet, Tecrübe, Eğitim düzeyi, İletişim becerisi, Fiziksel } \\
\text { Özellikleri, Kişilik özellikleri ve Devamlılık Kriterlerini }\end{array}$ \\
\hline Adalı (2016) & $\begin{array}{l}\text { Özel bir hastane için } \\
\text { hemşire seçimi }\end{array}$ & $\begin{array}{l}\text { Sözlü İletişim yeteneği, Ekip çalışmasına yatkınlık, } \\
\text { Yönetim ve Organizasyon yeteneği, Deneyim, Maliyet }\end{array}$ \\
\hline $\begin{array}{l}\text { Esen vd. (2019) } \\
\text { yaptıkları } \\
\text { araştırmada }\end{array}$ & $\begin{array}{l}\text { Acil bakım hemşiresi } \\
\text { programına } \\
\text { adaylar arasında seçim } \\
\text { başvuran }\end{array}$ & $\begin{array}{l}\text { Tecrübe, Eğitim durumu Yaş, Sertifikalı çalışan oranı, } \\
\text { Başuru ili, ilgili alanda çalışma durumu, }\end{array}$ \\
\hline
\end{tabular}

Başol vd. (2018) yaşlı bakım ve huzurevi çalışanlarının tükenmişlik düzeylerini ve çalışma yaşamı kalitesi algı düzeylerini incelemişledir. Çalışmada bakım elemanlarının duygusal ve fiziksel olarak tükenmişlik düzeyleri ve nedenlerini incelemişlerdir. Çalışmada bakım elemanları ile iletişim kurulması, hizmet içi eğitim verilmesi, iş yükünün azaltılması, stresle baş etme gibi psikolojik eğitimler verilmesini önermişleridir.

Alan ve Yıldırım (2016) hemşirelerin iş yaşam kalitesini etkileyen faktörleri incelmişlerdir. İş yaşam kalitesi üzerinde haftalık çalışma saatleri, mesleki tecrübe, fiziksel şartlar, sosyal ortam, örgütsel iletişim seviyesi, şeffaf, güvenilir yönetim kültürün etkili olduğu ifade edilmiştir.

Çimen vd. (2011) özel bakım merkezlerinde çalışan personelin iş doyumu ve tükenmişlik düzeyini incelemişleridir. Çalışmada iş doyumu ve tükenmişlik arasında ters yönlü korelasyon 
bulunmuştur. Çalışmada hasta ve yaşlı insanlara hizmet vermenin zor bir iş olduğu ve bu hizmeti sunan çalışanların çalışma koşullarında iyileştirmelerin yapılması, sosyal imkânların artırılarak bu çalışanlara destek verilmesi gerekliliğini vurgulamışlardır.

Yaşlı bakım elemanı seçim ve değerlendirmesinde etkili olan karar kriterleri belirlendikten sonra yönetici konumundaki üç karar verici Tablo 1'de verilen dilsel değişkenleri kullanarak kriterlerin önem ağırlıklarını değerlendirmiştir. Kriterlerin karar vericiler tarafından yapılan dilsel değerlendirmeleri Tablo 4'te verilmiştir.

Tablo 4. Karar Vericilerin Kriterler İçin Dilsel Değerlendirmesi

\begin{tabular}{llllllll}
\hline & $C_{1}$ & $C_{2}$ & $C_{3}$ & $C_{4}$ & $C_{5}$ & $C_{6}$ & $C_{7}$ \\
\hline KV1 & O & BD & ÇY & ÇY & Y & BY & O \\
\hline KV2 & BD & O & Y & Y & Y & Y & BY \\
\hline KV3 & O & BD & ÇY & ÇY & Y & BY & O \\
\hline
\end{tabular}

Dilsel değişkenler kullanılarak yapılan değerlendirmeler Tablo 1'deki bulanık sayılar ile ifade edilerek Tablo 5'te verilmiştir.

Tablo 5. Kriter Değerlendirmelerinin Bulanıklaştırılması

\begin{tabular}{|c|c|c|c|c|c|c|c|}
\hline & $C_{1}$ & $C_{2}$ & $C_{3}$ & $C_{4}$ & $C_{5}$ & $C_{6}$ & $C_{7}$ \\
\hline KV1 & $(0,30,50,7)$ & $(0,10,30,5)$ & $\left(\begin{array}{llll}0,9 & 1 & 1\end{array}\right)$ & $\left(\begin{array}{llll}0,9 & 1 & 1\end{array}\right)$ & $\begin{array}{l}(0,7 \\
0,91) \\
\end{array}$ & $(0,50,70,9)$ & $(0,30,50,7)$ \\
\hline KV2 & $(0,10,30,5)$ & $(0,30,50,7)$ & $(0,70,91)$ & $(0,70,91)$ & $\begin{array}{l}(0,7 \\
0,91)\end{array}$ & $(0,7$ 0,9 1) & $(0,50,70,9)$ \\
\hline KV3 & $(0,30,50,7)$ & $(0,10,30,5)$ & $\left(\begin{array}{llll}0,9 & 1 & 1\end{array}\right)$ & $\left(\begin{array}{lll}0,9 & 1 & 1\end{array}\right)$ & $\begin{array}{l}(0,7 \\
0,91)\end{array}$ & $(0,50,70,9)$ & $(0,30,50,7)$ \\
\hline $\begin{array}{l}\text { A, } \\
\text { ORT, }\end{array}$ & $\begin{array}{ll}(0,233 & 0,433 \\
0,633)\end{array}$ & $\begin{array}{ll}(0,167 & 0,367 \\
0,567) & \\
\end{array}$ & $\begin{array}{l}(0,833 \\
0,9671)\end{array}$ & $\begin{array}{l}(0,833 \\
0,9671)\end{array}$ & $\begin{array}{l}(0,7 \\
0,91)\end{array}$ & $\begin{array}{l}(0,5670,767 \\
0,933)\end{array}$ & $\begin{array}{l}(0,3670,567 \\
0,767)\end{array}$ \\
\hline
\end{tabular}

Karar vericilerce yapılan bulanık sayı değerlendirmeleri formül (2) kullanılarak aritmetik ortalama yolu ile birleştirilmiş ve kriterlerin bulanık önem ağırlıkları elde edilmiştir. Kriterlerin elde edilen bulanık önem ağırlıkları Tablo 6'da verilmiştir.

Tablo 6. Kriterlerin Bulanık Ağırlıkları

\begin{tabular}{llll}
\hline Kriterler & \multicolumn{3}{l}{ Bulanık Ağırlıklar } \\
\hline$C_{1}$ & $(0,233$ & 0,433 & $0,633)$ \\
\hline$C_{2}$ & $(0,167$ & 0,367 & $0,567)$ \\
\hline$C_{3}$ & $(0,833$ & 0,967 & $1,000)$ \\
\hline$C_{4}$ & $(0,833$ & 0,967 & $1,000)$ \\
\hline$C_{5}$ & $(0,700$ & 0,900 & $1,000)$ \\
\hline$C_{6}$ & $(0,567$ & 0,767 & $0,933)$ \\
\hline$C_{7}$ & $(0,367$ & 0,567 & $0,767)$ \\
\hline
\end{tabular}

Kriterlerin önem ağırlıkları incelendiğinde en önemli kriterlerin "Sabırlı Olma ve Strese Dayanıklı Olma", "Empati Yapabilme ve Nazik Olma" ve "Mahremiyete ve Özel Hayatın 1976 
Gizliliğine Saygılı Olma” kriterlerinin olduğu görülmektedir. Yapılan görüşmelerde uzmanlar, bireylerin yaşa bağlı problemler yaşadıklarını ifade etmişlerdir. Örneğin yaşlıların aynı soruyu defalarca sormaları karşısında bakım elemanlarının sabırlı ve şefkatli olmalarının önemli olduğunu belirtmişlerdir. Aynı şekilde sabırlı ve şefkatli olma tutumunun gelişmesi ve yaşlı bireylerle iyi ilişkiler geliştirmenin empati kurma yoluyla geliştirilebileceğini belirtmişlerdir. Görüşmelerde, toplu halde yaşanılan bakımevlerinde özel hayatın gizliliğinin çok önemli olduğu ve çalışanların bu konuda özenli olmalarının gerektiği belirtilmiştir. "Tecrübe" ve "Mesleki Bilgi”" kriterlerinin en az önemli kriter olarak belirlendiği görülmüştür. Uzmanlar, mesleki bilgi ve tecrübenin önemli olmakla birlikte çalışılan sektörde duygusal yeteneklerin çok önemli olduğunu belirtmişlerdir.

Kriterlerin bulanık önem ağırlıklarının belirlenmesinden sonra bir özel yaşlı bakım merkezine başvuruda bulunan beş aday, yönetici pozisyonundaki üç karar verici uzman tarafindan Tablo 1'de verilen dilsel değiş̧kenler kullanılarak her bir kritere göre değerlendirilmiştir. Adayların dilsel değişkenler kullanılarak yapılan değerlendirmeleri Tablo 7'de verilmiştir.

Tablo 7. Adayların Kriterlere Göre Dilsel Değerlendirilmesi

\begin{tabular}{|c|c|c|c|c|c|c|c|c|}
\hline Alternatif & $\begin{array}{c}\text { Kriterler } \\
\text { Karar Verici }\end{array}$ & $C_{1}$ & $C_{2}$ & $C_{3}$ & $C_{4}$ & $C_{5}$ & $C_{6}$ & $C_{7}$ \\
\hline \multirow{3}{*}{$A_{1}$} & KV1 & $\mathrm{O}$ & BK & $\mathrm{O}$ & Bİ & $\mathrm{BK}$ & $\mathrm{O}$ & $\mathrm{O}$ \\
\hline & KV2 & $\mathrm{O}$ & K & $\mathrm{O}$ & Bİ & $\mathrm{BK}$ & Bİ & BK \\
\hline & KV3 & Bİ & Bİ & $\mathrm{O}$ & $\mathrm{O}$ & $\mathrm{BK}$ & İ & $\mathrm{O}$ \\
\hline \multirow{3}{*}{$A_{2}$} & KV1 & $\mathrm{BK}$ & BK & $\mathrm{BK}$ & $\mathrm{O}$ & $\mathrm{BK}$ & $\mathrm{O}$ & $\mathrm{O}$ \\
\hline & KV2 & $\mathrm{BK}$ & $\mathrm{O}$ & $\mathrm{O}$ & $\mathrm{BK}$ & $\mathrm{O}$ & BK & $\mathrm{O}$ \\
\hline & KV3 & BK & $\mathrm{BK}$ & $\mathrm{O}$ & Bİ & $\mathrm{O}$ & BK & BK \\
\hline \multirow{3}{*}{$A_{3}$} & KV1 & $\dot{I}$ & Bİ & $\mathrm{BK}$ & $\mathrm{BK}$ & $\mathrm{O}$ & $\mathrm{O}$ & $\mathrm{O}$ \\
\hline & KV2 & $\mathrm{O}$ & $\mathrm{O}$ & $\mathrm{O}$ & $\mathrm{O}$ & $\mathrm{BK}$ & BK & Bİ \\
\hline & KV3 & $\dot{I}$ & $\dot{I}$ & Bİ & Bİ & $\mathrm{O}$ & $\mathrm{O}$ & $\mathrm{O}$ \\
\hline \multirow{3}{*}{$A_{4}$} & KV1 & $\mathrm{O}$ & $\mathrm{O}$ & $\dot{I}$ & Çİ & Bİ & $\mathrm{O}$ & BK \\
\hline & KV2 & Bİ & Bİ & Bİ & Bİ & Bİ & $\mathrm{O}$ & $\mathrm{O}$ \\
\hline & KV3 & Bİ & $\mathrm{O}$ & $\mathrm{O}$ & $\mathrm{O}$ & $\dot{I}$ & $\dot{\mathrm{I}}$ & $\mathrm{O}$ \\
\hline \multirow{3}{*}{$A_{5}$} & KV1 & $\mathrm{O}$ & $\mathrm{O}$ & $\mathrm{O}$ & $\mathrm{O}$ & Bİ & Bİ & Bİ \\
\hline & KV2 & $\mathrm{O}$ & $\mathrm{O}$ & Bİ & $\dot{I}$ & Bİ & $\mathrm{O}$ & Bİ \\
\hline & KV3 & Bİ & Bİ & Bİ & Bİ & Bİ & $\mathrm{O}$ & Bİ \\
\hline
\end{tabular}

Daha sonra adayların her bir kritere göre dilsel değerlendirmeleri Tablo 1'de verilen üçgen bulanık sayılar ile bulanıklaştırılmıştır. Adayların kriterlere göre değerlendirilmeleri üçgen bulanık sayılar ile ifade edilerek Tablo 8'de verilmiştir. 
Tablo 8. Alternatiflerin Dilsel Değerlendirmelerinin Bulanıklaştırılması

\begin{tabular}{|c|c|c|c|c|c|c|}
\hline \multicolumn{7}{|c|}{ Alternatifler } \\
\hline Kriterler & $\begin{array}{l}\text { Karar } \\
\text { Verici }\end{array}$ & $A_{1}$ & $A_{2}$ & $A_{3}$ & $A_{4}$ & $A_{5}$ \\
\hline \multirow{3}{*}{$C_{1}$} & KV1 & $(357)$ & $\left(\begin{array}{lll}1 & 3 & 5\end{array}\right)$ & $\left(\begin{array}{lll}7 & 9 & 10\end{array}\right)$ & $(357)$ & $(357)$ \\
\hline & KV2 & $(357)$ & $\left(\begin{array}{lll}1 & 3 & 5\end{array}\right)$ & (35 7) & (5 79$)$ & $(357)$ \\
\hline & KV3 & (5 79 ) & (1 35 ) & $(7910)$ & (5 79) & (5 79$)$ \\
\hline \multirow{3}{*}{$C_{2}$} & KV1 & $\left(\begin{array}{lll}1 & 3 & 5\end{array}\right)$ & $\left(\begin{array}{lll}1 & 3 & 5\end{array}\right)$ & (5 79 ) & $(357)$ & $(357)$ \\
\hline & KV2 & $\left(\begin{array}{lll}0 & 1 & 3\end{array}\right)$ & (357) & (357) & (5 79$)$ & (3 57 ) \\
\hline & KV3 & (5 79) & $(135)$ & $\left(\begin{array}{lll}7 & 9 & 10\end{array}\right)$ & $(357)$ & (5 79$)$ \\
\hline \multirow{3}{*}{$C_{3}$} & KV1 & $(357)$ & $\left(\begin{array}{lll}1 & 3 & 5\end{array}\right)$ & $\left(\begin{array}{lll}1 & 3 & 5\end{array}\right)$ & $(7910)$ & $(357)$ \\
\hline & KV2 & $(357)$ & $(357)$ & (357) & (5 79 ) & (5 79$)$ \\
\hline & KV3 & (357) & (35 7) & (5 79$)$ & $(357)$ & (5 79$)$ \\
\hline \multirow{3}{*}{$C_{4}$} & KV1 & (5 79) & $(357)$ & $\left(\begin{array}{lll}1 & 3 & 5\end{array}\right)$ & $\left(\begin{array}{lll}9 & 10 & 10\end{array}\right)$ & (3 57 ) \\
\hline & KV2 & (5 79 ) & (1 35 ) & $(357)$ & (5 79) & $\left(\begin{array}{lll}7 & 9 & 10\end{array}\right)$ \\
\hline & KV3 & (35 7) & (579) & (5 79$)$ & $(357)$ & (5 79$)$ \\
\hline \multirow{3}{*}{$C_{5}$} & KV1 & $\left(\begin{array}{lll}1 & 3 & 5\end{array}\right)$ & (1 35$)$ & (357) & (5 79 ) & (5 79$)$ \\
\hline & $\mathrm{KV} 2$ & $(135)$ & $(357)$ & $\left(\begin{array}{lll}1 & 3 & 5\end{array}\right)$ & (5 79 ) & (5 79$)$ \\
\hline & KV3 & $\left(\begin{array}{lll}1 & 3 & 5\end{array}\right)$ & $(357)$ & $(357)$ & $(79$ 10) & (5 79$)$ \\
\hline \multirow{3}{*}{$C_{6}$} & KV1 & $(357)$ & $(357)$ & $(357)$ & $(357)$ & (5 79$)$ \\
\hline & KV2 & (5 79) & (1 35 ) & $(135)$ & $(357)$ & $(357)$ \\
\hline & KV3 & $(79$ 10) & $\left(\begin{array}{lll}1 & 3 & 5\end{array}\right)$ & $(357)$ & $(79$ 10) & $(357)$ \\
\hline \multirow{3}{*}{$C_{7}$} & KV1 & $(357)$ & $(357)$ & (357) & $(135)$ & (5 79) \\
\hline & $\mathrm{KV} 2$ & (1 35 ) & $(357)$ & (5 79) & $(357)$ & (5 79$)$ \\
\hline & KV3 & $(357)$ & (1 35 ) & (3 57 ) & $(357)$ & (5 79 ) \\
\hline
\end{tabular}

Adayların karar vericiler tarafından kriterlere göre üçgen bulanık sayılar ile ifade edilen değerlendirmeleri formül (3) kullanılarak birleştirilmiştir. Bulanık sayıların birleştirilmesi ile bulanık karar matrisi elde edilmiştir. Elde edilen bulanık karar matrisi Tablo 9'da verilmiştir.

Tablo 9. Bulanık Karar Matrisi

\begin{tabular}{rlllllllllr}
\hline & $A_{1}$ & & $A_{2}$ & & \multicolumn{1}{c}{$A_{3}$} & & $A_{4}$ & \multicolumn{3}{c}{$A_{5}$} \\
\\
\multirow{2}{*}{$C_{1}$} & $(3,667$ & 5,667 & $(1,000$ & 3,000 & $(5,667$ & 7,333 & $(4,333$ & 6,333 & $(3,667$ & 5,667 \\
& $7,667)$ & & $5,000)$ & & $9,000)$ & & $8,333)$ & & $7,667)$ & \\
\hline \multirow{2}{*}{$C_{2}$} & $(2,000$ & 3,667 & $(1,667$ & 3,667 & $(5,000$ & 7,000 & $(3,667$ & 5,667 & $(3,667$ & 5,667 \\
& $5,667)$ & & $5,667)$ & & $8,667)$ & & $7,667)$ & & $7,667)$ & \\
\hline
\end{tabular}


ALANYA AKADEMİK BAKIŞ DERGİSİ 6/1 (2022)

\begin{tabular}{lllllllllll}
\hline \multirow{2}{*}{$C_{3}$} & $(3,000$ & 5,000 & $(2,333$ & 4,333 & $(3,000$ & 5,000 & $(5,000$ & 7,000 & $(4,333$ & 6,333 \\
& $7,000)$ & & $6,333)$ & & $7,000)$ & & $8,667)$ & & $8,333)$ & \\
\hline \multirow{2}{*}{$C_{4}$} & $(4,333$ & 6,333 & $(3,000$ & 5,000 & $(3,000$ & 5,000 & $(5,667$ & 7,333 & $(5,000$ & 7,000 \\
& $8,333)$ & & $7,000)$ & & $7,000)$ & & $8,667)$ & & $8,667)$ & \\
\hline \multirow{2}{*}{$C_{5}$} & $(1,000$ & \multirow{2}{*}{3,000} & $(2,333$ & 4,333 & $(2,333$ & 4,333 & $(5,667$ & 7,667 & $(5,000$ & 7,000 \\
& $5,000)$ & & $6,333)$ & & $6,333)$ & & $9,333)$ & & $9,000)$ & \\
\hline \multirow{2}{*}{$C_{6}$} & $(5,000$ & 7,000 & $(1,667$ & \multirow{2}{*}{3,667} & $(2,333$ & 4,333 & $(4,333$ & 6,333 & $(3,667$ & 5,667 \\
& $8,667)$ & & $5,667)$ & & $6,333)$ & & $8,000)$ & & $7,667)$ & \\
\hline \multirow{2}{*}{$C_{7}$} & $(2,333$ & 4,333 & $(2,333$ & 4,333 & $(3,667$ & 5,667 & $(2,333$ & 4,333 & $(5,000$ & 7,000 \\
& $6,333)$ & & $6,333)$ & & $7,667)$ & & $6,333)$ & & $9,000)$ & \\
\hline
\end{tabular}

Bulanık karar matrisinden hareketle her bir kriter için formül (6)'dan yararlanarak en iyi $\tilde{f}_{j}^{*}$ ve en kötü değerler $\tilde{f}_{j}^{-}$bulunarak Tablo 10'da verilmiştir.

Tablo 10. Kriterlerin En İyi ve En Kötü Değerleri

\begin{tabular}{lll}
\hline & $\tilde{f}_{j}^{*}$ & \multicolumn{1}{c}{$\tilde{f}_{j}^{-}$} \\
\hline$C_{1}$ & $(5,6677,3339,000)$ & $(1,0003,0005,000)$ \\
\hline$C_{2}$ & $(5,0007,0008,667)$ & $(1,6673,6675,667)$ \\
\hline$C_{3}$ & $(5,0007,0008,667)$ & $(2,3334,3336,333)$ \\
\hline$C_{4}$ & $(5,6677,3338,667)$ & $(3,0005,0007,000)$ \\
\hline$C_{5}$ & $(5,6677,6679,333)$ & $(1,0003,0005,000)$ \\
\hline$C_{6}$ & $(5,0007,0008,667)$ & $(1,6673,6675,667)$ \\
\hline$C_{7}$ & $(5,0007,0009,000)$ & $(2,3334,3336,333)$ \\
\hline
\end{tabular}

Her bir kriter için en iyi $\tilde{f}_{j}^{*}$ ve en kötü değerin $\tilde{f}_{j}^{-}$bulunmasından sonra alternatiflerin en iyi bulanık değere uzaklığının toplamını ifade eden $\tilde{S}_{j}$ değeri formül (8) kullanılarak hesaplanmıştır. $\tilde{S}_{j}$ değerleri ve durulaştırılmış değerleri Tablo 11 'de verilmiştir. $\tilde{S}_{j}$ değerleri formül (13) kullanılarak durulaştırılmıştır.

Tablo 11. Alternatiflerin En İyi Değere Uzaklıkları

\begin{tabular}{lll}
\hline & $\tilde{S}_{j}$ & $B N P_{i}$ \\
\hline$A_{1}$ & $(2,3583,1593,459)$ & 2,992 \\
\hline$A_{2}$ & $(3,5004,7105,592)$ & 4,601 \\
\hline$A_{3}$ & $(2,5953,2313,516)$ & 3,114 \\
\hline$A_{4}$ & $(0,6130,9901,269)$ & 0,957 \\
\hline$A_{5}$ & $(0,9100,9060,931)$ & 0,916 \\
\hline
\end{tabular}


Her bir kriter için alternatiflerin en iyi bulanık değere uzaklığının toplamını ifade eden $\tilde{R}_{j}$ değeri formül (9) kullanılarak hesaplanmıştır. $\tilde{R}_{j}$ değerleri ve durulaştırılmış değerleri Tablo 12 'de verilmiştir. $\tilde{R}_{j}$ değerleri formül (13) kullanılarak durulaştırılmıştır.

Tablo 12. Alternatiflerin En Kötü Değere Uzaklıkları

\begin{tabular}{lcl}
\hline & $\tilde{R}_{j}$ & $B N P_{i}$ \\
\hline$A_{1}$ & $(0,7000,9001,000)$ & 0,867 \\
\hline$A_{2}$ & $(0,8330,9671,000)$ & 0,933 \\
\hline$A_{3}$ & $(0,8330,9671,000)$ & 0,933 \\
\hline$A_{4}$ & $(0,3670,5670,767)$ & 0,567 \\
\hline$A_{5}$ & $(0,2270,3070,311)$ & 0,281 \\
\hline
\end{tabular}

Maksimum grup faydası değeri $\tilde{S}^{*}$ ve karşıt görüştekilerin minumum pişmanlık değeri $\tilde{R}^{*}$ sırasıyla formül (10) ve (11)'den yararlanılarak hesaplanmış ve Tablo 13'te verilmiştir.

Tablo 13. $\tilde{S}^{*}, \tilde{S}^{-}, \tilde{R}^{*}$ ve $\tilde{R}^{-}$değerleri

\begin{tabular}{cl}
\hline$\tilde{S}^{*}$ (Min.) & $(0,6130,9901,269)$ \\
\hline$\tilde{S}^{-}$(Mak.) & $(3,5004,7105,592)$ \\
\hline$\tilde{R}^{*}$ (Min.) & $(0,2270,3070,311)$ \\
\hline$\tilde{R}^{-}$(Mak.) & $(0,8330,9671,000)$
\end{tabular}

Maksimum grup faydası ve karşı görüştekilerin minumum pişmanlık değeri bulunduktan sonra bu değerler kullanılarak ve formül (12)'den yararlanılarak her bir alternatif için $\tilde{Q}_{i}$ indeks değeri hesaplanmış ve Tablo 14 'te verilmiştir. $\tilde{Q}_{i}$ değerleri formül (13) kullanılarak durulaştırılmıştır. Uzlaşma değeri ' $v$ ’ 0,50 olarak alınmıştır.

Tablo 14. Alternatiflerin Uzlaşık Değerleri

\begin{tabular}{lll}
\hline & $Q_{i}$ & $B N P_{i}$ \\
\hline$A_{1}$ & $(0,6920,7410,222)$ & 0,552 \\
\hline$A_{2}$ & $(1,0001,0001,000)$ & 1,000 \\
\hline$A_{3}$ & $(0,8430,8010,760)$ & 0,801 \\
\hline$A_{4}$ & $(0,1150,1970,331)$ & 0,214 \\
\hline$A_{5}$ & $(0,051-0,011-0,039)$ & 0,000 \\
\hline
\end{tabular}

Ede edilen $Q_{i}, S_{i}$ ve $R_{i}$ değerlerinin durulaştırılmış değerleri Tablo 15 'te verilmişsir. Durulaştırılmış değerler diğer bir ifadeyle bulanık sayıların ortalama değerlerini vermektedir. $\mathrm{Bu}$ değerlere göre alternatifler küçükten büyüğe doğru sıralanmıştır. İndeks değerleri içinde en küçük olan en iyi alternatifi vermektedir. 
Tablo 15. $S_{i}, R_{i}, Q_{i}$ İndeks Değerleri ve Durulaştırılmış Değerleri

\begin{tabular}{lllllll}
\hline & $S_{i}$ & Siralama & $R_{i}$ & Siralama & $Q_{i}$ & Siralama \\
\hline$A_{1}$ & 2,992 & 3 & 0,867 & 3 & 0,552 & 3 \\
\hline$A_{2}$ & 4,601 & 5 & 0,933 & 4,5 & 1,000 & 5 \\
\hline$A_{3}$ & 3,114 & 4 & 0,933 & 4,5 & 0,801 & 4 \\
\hline$A_{4}$ & 0,957 & 2 & 0,567 & 2 & 0,214 & 2 \\
\hline$A_{5}$ & 0,916 & 1 & 0,281 & 1 & 0,000 & 1 \\
\hline
\end{tabular}

Sonuçlara göre sıralamada en küçük iki $Q_{i}$ indeks değeri arasındaki fark 0,000- 0,214<0,25 olduğu için 1 . Koşul olan kabul edilebilir avantaj koşulu sağlanmamıştır. Ancak $Q_{i}$ indeks değerlerinin küçükten büyüğe doğru sıralaması $S_{i}$ ve $R_{i}$ indeks değeri için de aynıdır. Bu durum Tablo 15 'te görülmektedir. Bu durumda 2. Koşul olan kabul edilebilir istikrar koşulu sağlanmaktadır. $A_{5}$ alternatifi karşılaştırmalı bir üstünlüğe sahip değildir. Ancak en küçük iki değer olan $A_{5}$ ve $A_{4}$ uzlaştırıcı çözümlerdir. Buna göre $A_{5}$ en iyi aday olarak değerlendirilmiştir. $A_{5}$ adayından sonraki en iyi aday $A_{4}$ adayıdır. Sırasıyla $A_{5}, A_{4}, A_{1}, A_{3} v e A_{2}$ uzlaştırıcı çözümler olarak kabul edilir.

Tablo 16. $Q_{i}, S_{i}$ ve $R_{i}$ Değerlerine Göre Alternatiflerin Sıralaması

\begin{tabular}{ll}
\hline$Q_{i}$ & $A_{5} \succ A_{4} \succ A_{1} \succ A_{3} \succ A_{2}$ \\
\hline$S_{i}$ & $A_{5} \succ A_{4} \succ A_{1} \succ A_{3} \succ A_{2}$ \\
\hline$R_{i}$ & $A_{5} \succ A_{4} \succ A_{1} \succ A_{3} \succ A_{2}$
\end{tabular}

\section{SONUÇ VE DEĞERLENDİRME}

Ekonomilerde iş gücü istihdamına en çok katkıyı hizmet sektörünün yaptığı görülmektedir. Hizmet sektöründe üretilen ürün, soyut mal olarak ifade edilmekte ve somut ürünlerden farklı özellikler göstermektedir. Hizmet sektöründe üretilen soyut malların depolanamaması, anında tüketilmesi ve kalitesinin sunan ve tüketen tarafından üretildiği anda belirlenmesi önemli özelliklerindendir. Hizmet kalitesi büyük ölçüde hizmeti üreten kişiye bağlıdır. Bu nedenle hizmet sektöründe faaliyet gösteren işletmelerin en önemli kaynağı sahip oldukları nitelikli insan gücüdür. Doğru personeli işe alarak istihdam etmek bu alanda faaliyet gösteren işletmelerin kârlılık ve devamlılığı için çok önemlidir. Bununla birlikte personel değerlendirmesinde nicel kriterler yanında dilsel değişkenlerin kullanıldığı nitel kriterlerin de dikkate alınması nedeniyle personel seçim ve değerlendirmesi bulanık karar problemi olarak ortaya çıkmaktadır.

Çocuk ve yaşlı bakım hizmetleri, hizmet sektörünün çok özel ve hassas alanlarıdır. Hizmet alan kişiler daha kırılgan, ilgi ve bakıma muhtaç kişilerdir. Bu bağlamda yaşlı bakım merkezlerinde çalışan bakım elemanlarının seçimi, özel yeteneklerin ve kişilik özelliklerinin öne çıktığ 1 karar problemleridir. $\mathrm{Bu}$ yönüyle yaşı bakım elemanı seçimi nitel kriterler içermekte ve dilsel değerlendirmeler kullanılmaktadır. $\mathrm{Bu}$ çalışmada bulanık çok kriterli karar verme yöntemlerinden bulanık VIKOR yöntemi ile yaşlı bakım elemanı seçimi yapılmıştır. 
Çalışmada özel bir yaşlı bakımevi için yedi kritere göre üç uzman karar verici tarafindan beş yaşı ıakım elemanı adayı arasından yaşı bakım elemanı seçimi yapılmıştır. Bulanık VIKOR yönteminde üçgen bulanık sayılar kullanılmıştır. Çalışmada öncelikle belirlenen kriterlerin bulanık önem ağırlıkları belirlenmiştir. "Sabırlı Olma ve Strese Dayanıklı Olma", "Empati Yapabilme ve Nazik Olma" ve "Mahremiyete ve Özel Hayatın Gizliliğine Saygılı Olma" kriterleri öne çıkan kriterler olmuştur. Daha sonra kriterlere göre adaylar dilsel değişkenler ile değerlendirilmiş, bulanık VIKOR yöntemi ile beş aday arasından $A_{5}$ en uygun aday olarak belirlenmiştir.

Çalışmada kullanılan bulanık VIKOR karar verme yöntemi, yaşlı bakım elemanı seçiminde ve yaşıı bakım elemanlarının performans ölçümünde uygulanabilir bir yöntem olarak değerlendirilmiştir. Bulanık VIKOR yöntemi farklı sektörlerde eleman seçimi problemlerinde farklı yöntemlerle bütünleşik olarak kullanıldığı görülmektedir.

Sağlık sektörünün önemli bir bölümü olan yaşlı bakım merkezi ve huzurevlerinde işgören devir hızının yüksek olduğu görüşülen yönetici ve uzmanlarca ifade edilmiştir. Bu durumun temel nedeni olarak bakım elemanlarının yetenek ve kişisel özelliklerinin işin gerektirdiği nitelikte olmadığı ve bu nedenle iş değiştirmelerin yaşandığı ifade edilmiştir. Bu durum zor ve hassas bir hizmet kolu olan bakım merkezleri ve huzurevlerinde, personel seçiminin daha titiz ve daha ayrıntılı değerlendirmeler ile yapılması gerektiğini ortaya koymaktadır. Bu amaçla bu alanda yapılacak yeni çalışmalarda kişisel özellikler ve yeteneklerin tespitine yönelik çalışmalara odaklanılması yararlı olacaktır.

Yapılacak araştırmalarda karar problemindeki kriterlerin değişmesi ya da önem ağırlıklarının değişmesi durumunda sonuçlar da değişecektir. Gelecekte yapılacak çalışmalarda farklı bulanık karar verme yöntemleri kullanılarak seçim ve değerlendirme kriterleri daha kapsamlı belirlenerek ele alınabilir. Bu alanda yapılacak farklı bulanık karar verme yöntemleriyle kriter önem ağırlıklarının belirlenmesi ve alternatiflerin değerlendirilmesi literatüre katkılar sağlayacaktır.

\section{KAYNAKÇA}

ADALI, E. A. (2016). Personnel selection in health sector with EVAMIX and TODIM methods. Alphanumeric Journal, 4(2), 69-84.

AİLE VE SOSYAL HIZMETLER BAKANLIĞI, https://www.aile.gov.tr/media/88684/eyhgm_istatistik_bulteni_temmuz2021.pdf (Erişim tarihi 01.09.2021).

AKSAKAL, E., \& DAĞDEVIREN, M. (2010). ANP ve DEMATEL yöntemleri ile personel seçimi problemine bütünleşik bir yaklaşim. Gazi Üniversitesi Mühendislik Mimarlık Fakültesi Dergisi, 25(4).

AKYÜZ, G. A. (2012). "Bulanık VIKOR yöntemi ile tedarikçi seçimi”. Atatürk Üniversitesi İktisadi ve İdari Bilimler Dergisi, 26(1), 197-215.

ALAN, H., \& YILDIRIM, A. (2016). Hemşirelerin iş yaşam kalitesi ve etkileyen faktörlerin incelenmesi. Sağlık ve Hemşirelik Yönetimi Dergisi, 3(2), 86-98. 
ALGuliYEV, R. M., ALIGULIYEV, R. M., \& MAHMUDOVA, R. S. (2015). "Multicriteria personnel selection by the modified fuzzy VIKOR method". The Scientific World Journal, 2015.

AMİİ, M., AYAZİ, S. A., OLFAT, L., \& MORADİ, J. S. (2011). Group decision making process for supplier selection with VIKOR under fuzzy circumstance case study: an Iranian car parts supplier. International bulletin of business administration, 10(6), 6675 .

AYÇİN, E. (2020). Personel Seçim Sürecinde CRITIC ve MAIRCA Yöntemlerinin Kullanılması. İşletme, 1(1), 1-12.

BALİ, Ö. (2013). "Bulanık Boyut Analizi ve Bulanık VIKOR İle Bir ÇNKV Modeli: Personel Seçimi Problemi”. Kara Harp Okulu Bilim Dergisi, 23(2), 125-149.

BAŞOL, O., SAĞLAM, Y., \& ÇAKIR, N. N. (2018). Engelli Ve Yaşlı Bakım Personelinin Tükenmişlik Seviyeleri İle Çalışma Yaşamı Kalitesi Algısı İlişkisi. Toplum ve Sosyal Hizmet, 29(2), 71-97.

ÇELİKBİLEK, Y. (2018). Personel seçimi için bütünleşik gri AHP-MOORA yaklaşımının kullanılması: sağlık sektöründe yönetici seçimi üzerine bir uygulama. Alphanumeric Journal, 6(1), 69-82.

ÇİFTÇI, M., ZELKA, M. (2019). "Türkiye'de Yaşlı Bakımı Hizmetlerinin Gelişimi İstanbul İli Üzerine Bir Araştırma”. In Internatıonal Congress Of Management Economy And Policy 2019 Autumn Proceedings Book (P. 574).

ÇİMEN, M., ŞAHIN, B., AKBOLAT, M., \& IŞIK, O. (2012). Özel bakım merkezinde çalışan personelin tükenmişlik ve iş doyum düzeylerine yönelik bir çalışma. Acıbadem Üniversitesi Sağlık Bilimleri Dergisi, (1), 21-31.

EREBAK, S., TARHAN, Z.(2018). "Yaşıı Bakım Kuruluşlarında Çalışmak: Tutum, Duygusal Emek Ve İş-Yaşam Dengesi Tatmini İlişkisi”. İşletme Bilimi Dergisi, 6(2), 115-133.

ERSOY, N. (2017) “Bulanık Ortamda Personel Seçimine Yönelik Karar Verme Süreci”. Sosyal Bilimler Araştırma Dergisi, 6(3), 67-75.

ERTUĞRUL, İ., \& ÖZÇíL, A. (2014). Çok kriterli karar vermede TOPSIS ve VIKOR yöntemleriyle klima seçimi. Çankırı Karatekin Üniversitesi İktisadi ve İdari Bilimler Fakültesi Dergisi, 4(1), 267-282.

ESEN, H., YİĞİT, V., \& GÜLDAN, S. (2019). Hastanelerde AHP Ve TOPSIS Yöntemi İle Personel Seçimi: Acil Bakım Hemşireliği Sertifikalı Eğitim Programı Örneği. Avrasya Sosyal ve Ekonomi Araştırmaları Dergisi, 6(12), 112-128.

HAMURCU, M., TAMER, E.(2018). "Kent İçi Ulaşım İçin Bulanık AHP Tabanlı VIKOR Yöntemi İle Proje Seçimi”. Engineering Sciences, 13(3), 217-228.

HSİEH, T. Y., LU, S. T., TZENG, G. H. (2004). "Fuzzy MCDM approach for planning and design tenders selection in public office buildings". International Journal Of Project Management, 22(7), 573-584. 
KAHRAMAN, C., CEBECI,, U., RUAN, D. (2004). "Multi-attribute comparison of catering service companies using fuzzy AHP: The case of Turkey". International Journal Of Production Economics, 87(2), 171-184.

KORKUSUZ POLAT, T., KARA N., (2021), ’Personel Seçiminde Bulanık DEMATEL ve Bulanık VIKOR Yöntemlerinin Uygulanması". Avrupa Bilim ve Teknoloji Dergisi, (23), 376-385.

KOYUNCU, O., \& ÖZCAN, M. (2014). Personel seçim sürecinde analitik hiyerarşi süreci ve TOPSIS yöntemlerinin karşılaştırılması: Otomotiv sektöründe bir uygulama. Hacettepe Üniversitesi İktisadi ve İdari Bilimler Fakültesi Dergisi, 32(2), 195-218.

KUŞAKCI, A. O., AYVAZ, B., ÖZTÜRK, F., \& SOFU, F. (2019). Bulanik MULTIMOORA İle Personel Seçimi: Havacilik Sektöründe Bir Uygulama. Niğde Ömer Halisdemir Üniversitesi Mühendislik Bilimleri Dergisi, 8(1), 96-110.

KRİSHANKUMAR, R., PREMALADHA, J., RAVICHANDRAN, K. S., SEKAR, K. R., MANIKANDAN, R., GAO, X. Z. (2020). "A novel extension to VIKOR method under intuitionistic fuzzy context for solving personnel selection problem". Soft Computing, 24(2), 1063-1081.

LİANG, D., ZHANG, Y., XU, Z., \& JAMALDEEN, A. (2019). "Pythagorean fuzzy VIKOR approaches based on TODIM for evaluating internet banking website quality of Ghanaian banking industry”. Applied Soft Computing, 78, 583-594.

NALBANT, K. G., \& OZDEMIR, Y. (2018). "Personnel Selection Using Fuzzy VIKOR Methodology. International Journal “of Management Science, 5(2), 10-17.

OPRİCOVİC, S., TZENG, G. H. (2004). Compromise solution by MCDM methods: A comparative analysis of VIKOR and TOPSIS". European Journal Of Operational Research, 156(2), 445-455.

OPRİCOVIC, S., TZENG, G. H. (2007). "Extended VIKOR method in comparison with outranking methods". European journal of operational research, 178(2), 514-529.

OPRICOVIC, S. (2011). "Fuzzy VIKOR with an application to water resources planning". Expert Systems with Applications, 38(10), 12983-12990.

ORGAN, A., \& KENGER, M. D. (2018). Bütünleşik Bulanık AHP-Bulanık MOORA Yaklaşımının Market Personeli Seçimi Problemine Uygulanması. Anemon Muş Alparslan Üniversitesi Sosyal Bilimler Dergisi, 6(ICEESS'18), 271-280.

ÖZBEK, A. (2017). Çok Kriterli Karar Verme Yöntemleri Ve Excel İle Problem Çözümü. Seçkin Yayıncılık, Ankara.

ÖZTÜRK, F., KAYA, G. K. (2020). "Personnel selection with fuzzy VIKOR: an application in automotive supply industry". Gazi University Science Journal: Part C Design and Technology, 8(1), 94-108.

PAKSOY, T., PEHLIVAN YAPICI, N. VE ÖZCEYLAN, E.(2013) Bulanık Küme Teorisi, Nobel yayınevi. Ankara. 
PELİT, E. \& AK, S. (2018). İnsan Kaynakları Yönetimi İşlevi Olarak Personel Bulma, Seçme Ve Personeli İşe Yerleştirme İle İlgili Sorunlar: Turizm İşletmeleri Örneğinde Teorik Bir İnceleme. İstanbul Aydın Üniversitesi Dergisi, 10(2), 39-74.

SALEHI, K. (2016). “An integrated approach of fuzzy AHP and fuzzy VIKOR for personnel selection problem". Global Journal of Management Studies and Researches, 3(3), 8995.

SUH, Y., PARK, Y., KANG, D. (2019). "Evaluating mobile services using integrated weighting approach and fuzzy VIKOR”. Plos one, 14(6), e0217786.

ŞEN, Z. (2009). Bulanık Mantık İlkeleri ve Modelleme:(Mühendislik ve Sosyal Bilimler). Su Vakfi. İstanbul.

TUİK,https://data.tuik.gov.tr/Bulten/Index?p=Elderly-Statistics-2020-37227 (Erişim tarihi 01.09.2021).

TÜRELİ ŞALVARCI N., \& MANAP DAVRAZ, G. (2016). Hizmet sektöründeki personelin seçiminde AHP ve VIKOR yönteminin kullanımı: özel hastaneler açısından bir inceleme. The Journal of Academic Social Science Studies, 44 (Spring II), 249, 262.

ÜNAL, Ö. F. (2011). Analitik Hiyerarşi Prosesi ve Personel Seçimi Alanında Uygulamaları. Journal Of Alanya Faculty Of Business/Alanya İsletme Fakültesi Dergisi, 3(2).

VARGÜN, Ü. H., DOĞAN, M., \& BAL, K. (2020). Muhasebe Birimi Personel Seçim Problemi: ENTROPİ Temelli MAUT Yöntemi Uygulaması. Mali Cözüm Dergisi, 30, 177-191.

YALILI, A., DÖNMEZ, Ç. F., KAPTAN, G. (2016). Türkiye'de Yaşlı Bakım Kurumlarına Dair Bir Değerlendirme. Sağlık Bilimleri ve Yaşam Dergisi, 1(1), 30-39.

YAVUZ, S., DEVECİ, M. (2014). "Bulanık TOPSIS ve bulanık VIKOR yöntemleriyle alışveriş merkezi kuruluş yeri seçimi ve bir uygulama”. Ege Akademik Bakış, 14(3), 463-479

YILDIRIM, B. I., UYSAL, F., \& ILGAZ, A. (2019). Havayolu işletmelerinde personel seçimi: ARAS yöntemi ile bir uygulama. Süleyman Demirel Üniversitesi Sosyal Bilimler Enstitüsü Dergisi, 2(33), 219-231.

YILDIZ, A., DEVECİ, M. (2013). "Bulanik VIKOR Yöntemine Dayali Personel Seçim Süreci/Based on Fuzzy VIKOR Approach to Personnel Selection Process". Ege Akademik Bakış, 13(4), 427-436.

ZADEH, A. L. (1965). "Fuzzy sets”, Information and Control, 8, 338-353. 